\title{
Development of enterprise innovative activity for leadership in production and economic systems
}

\author{
Svetlana Vasilyeva \\ Togliatti State University \\ Belorusskaya St., 14, 445020 Togliatti \\ Russian Federation \\ e-mail: svetlana23s@mail.ru \\ Liudmila Glukhova \\ Department of Management \\ Volzhsky University after V.N. Tatischev \\ Belorusskaya St., 16, 445020 Togliatti \\ Russian Federation \\ e-mail: prof.glv@yandex.ru \\ Raisa Krayneva \\ Department of Management \\ Volga Region State University of Service \\ Gagarina St., 4, 445017 Togliatti \\ Russian Federation \\ e-mail: raisa-krayneva@yandex.ru
}

\begin{abstract}
The competition and consequent struggle for a leading position in its market segment are an inseparable feature of the market economy. It is possible to achieve competitive advantage through the use of organizational, technical and economic changes, i.e. through the growth of innovative activity aimed at effective use of limited resources (technical, raw, human, information, etc.); the product/service quality improvement; price reduction of traded goods/services; cost reduction; sale increase, etc.

The importance and the role of increasing enterprise innovative activity in modern terms emphasize the problems of formation and development of industrial production through the application of innovative methods. This becomes very important in the context of achieving leadership and becoming a leader on the market.
\end{abstract}

\section{Introduction}

A large-scale modernization of the economy, involving the introduction of innovative management methods aimed at improving the efficiency of domestic production-economic systems (PES) is the priority direction of development of modern Russia. One of the Central problems of strategic management is to establish the comparative importance of internal and external sources of competitive PES advantages through the combination of resources and organizational skills (Drucker 2002). It is necessary to apply the methods of planning and providing the innovation activity with the resources for the sustainable functioning of production-economic systems, taking into account exogenous factors of deployment and replacement of technological structures that would allow the enterprises to implement proactive development strategies and lead the business (Etzkowitz 2000; Leydesdorff 2000; Lundvall 2002; Overdorf 2007). In addition, it is necessary to analyze the endogenous factors of change, i.e. take into account the complexity of industrial production and its features, determining the identity of approaches and methods of resource management in the innovation implementation (see e.g. Cohen 1990; Conceicao 1999; or Benner 2000; or Naushad et al. 2018).

The issues of enterprise resource management found their theoretical and methodological expression in the resource-oriented concept which became widespread in the 1970s and 1980s due to the aggravation of energy crises, increased competition and globalization of the world economy (Romer 1990). Furthermore, the problem of developing theinnovative formation methods and enterprise resources is the most relevant and is caused by the main contradictions and inconsistencies:

- lagging behind the level of innovation of domestic industrial production from global trends in technical and economic development; 
- fragmentation, isolation of innovation processes implemented at some enterprises due to the inefficiency of innovation policy in the country;

- time gap between the creation of innovations and their implementation due to the lack of financial and resource provision of basic and applied research in the priority areas of science development

- low innovative activity of industrial enterprises and scientific-technical organizations; lack of demand for innovations in the production sphere, etc.;

- differences in the approaches to the choice of directions, resultevaluation, determination of motivation ways, the management methods, the scale of financing innovative programs and the innovative process participants' projects;

- discrepancy between the methods used to manage the resource potential of industrial production and the pace of scientific and technological progress, the logic of the spread of the fifth and sixth technological structures, new production technologies and materials, etc.

Fundamental theoretical and empirical works of many scientists made a significant contribution to the study of various aspects of the functioning of enterprises, the effective use of resources as a component of strategic development and diversification.

Many foreign and domestic authors devoted their works to the problem of management of innovative development at the enterprises, including the industrial sector. Such foreign scientists, as Valenta (1985; 2007), Barney (1991), Smith (1995), Freeman (1995), Teece (1997), Avkiran (2001), Dodgson (2008), Niño-Amézquita et al. (2017), or Shevtsova et al. (2018), as well as many others made the most significant contribution to the formation of the science of innovation. In the same time, such Russian scientists as Ansoff (1999), Alekhina (2004), Travin (2002), Magura (2002), Fatkhutdinov (2008), Zlyvko et al. (2014), Korchagin et al. (2015), or Korneeva (2016) devoted their works to the issues of efficient using resources at the enterprises.

\section{Methodology of innovation assessment in production-economic systems}

Searching the ways for improvement of efficiency to ensure the sustainability of the operation and development in the terms of instability and dynamic changes in the environment is one of the basic tasks of PES which include industrial enterprises (see e.g. Saaty 2010). Efficiency is one of the most important indicators to identify the state of the system and to point out the patterns of change (development, transformation, etc.), to study and analyze the procedural aspects of the operation from the perspective of achieving the goal. In order to achieve sustainable development of the PES it is necessary to ensurea stable flow of various innovation types, i.e. to manage continuously and systematically all the aspects which create the capacity for innovation (innovation strategy, organizational structures, dynamic abilities, competence, creativity, culture, continuous review and improvement of activities within these aspects), as well as to have a set of necessary resources (see e.g. Lisin et al. 2015; 2016).

This is the resource provision which has a key importanceto ensure the effective implementation of innovations in the PES and the resources should be presented in the form of 5 clusters set (energy subsystem ES, transport subsystem - TrS, environmental subsystem - EnS, technological subsystem - TS and information subsystem - InS) (At the same time, a unique combination of resource clusters of the production-economic system is:

I - the source of implementation of any processeswhich occur in the system (ensuring the functioning);

II - a way of adapting to the changing conditions of the external environment (development);

III - the necessary condition for creating and maintaining competitive advantages (self-preservation).

Let's determine the sequence of the evaluation procedure to assess the innovation effectiveness implemented in the PES, the level of compliance of the resource provision with the nature and characteristics of the set tasks on forming competitive advantages and ensuring sustainable development through the introduction of innovations.

Figure 1 in the flow-chart notation presents a methodology developed to assess the level of formation and development of resource provision of innovations implemented in production-economic systems. Let's consider the stages presented in the Flow-chart in details.

In accordance with the replacement model of technological structures (TS), the company determines the state of its production and identifies the conformity of the products to a particular type of TS, taking into account the stages of the model of deployment and replacement of TS.

The strategic priorities of the enterprise's production development are determined on the basis of obtained informationtaking into account the state and regional programs of innovative development, as well as the production specifics, the level of scientific and technical achievements, available technological developments in the industry and the enterprise, etc. 


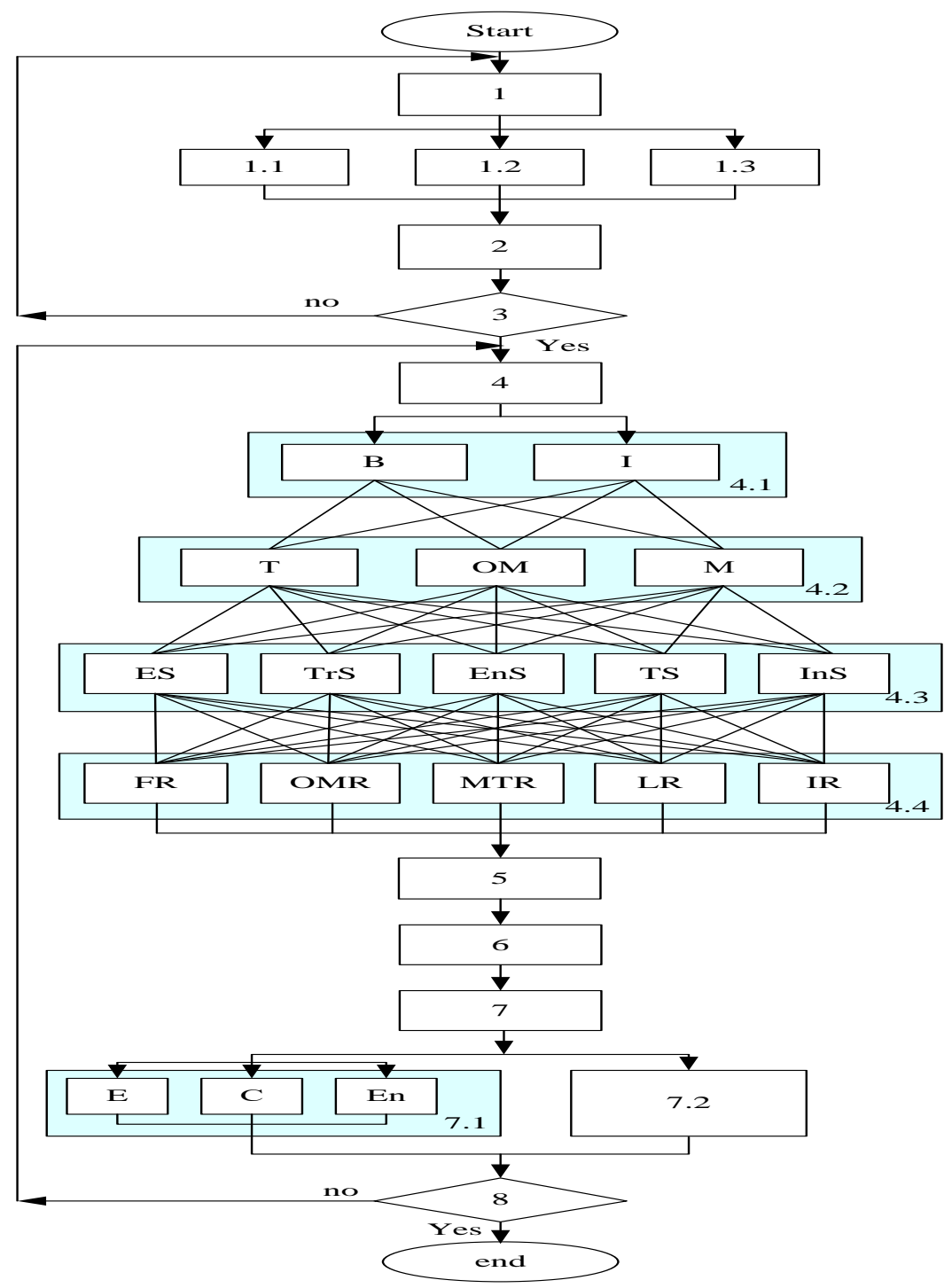

Fig.1. Methods for the assessment of the formation and development level of innovation resource provision in PES (Assessment Algorithm)

Source: Tolmacheva (2011)

The development (definition) of indicators is carried out in parallel to assess the degree of achievement of strategic goals in accordance with the priorities of the enterprise. After that, it is necessary to make a choice of adequate methods for evaluation of the selected indicators.

The next step is to assess the state of the resource support of the enterprise production taking into account the selected indicators and selected assessment methods. If the assessment results do not allow the implementation of the chosen development strategy, it is necessary to be revised (corrected). In addition, if the enterprise potential identified in the course of assessment has the appropriate reserves to ensure strategic development, it is necessary to specify the type of innovation or a set of innovations planned for the implementation at the enterprise.

\section{Results and discussions}

Using the method of hierarchy analysis, the choice of innovation (complex of innovations: basic (B), improving (I), technological (T), organizational and managerial (OM), marketing (M)) for implementation in the enterprise with the simulated coefficients of significance. Similarly, using the method of pairwise comparison, the assessment of the importance of resource clusters (energy subsystem (ES), transport (TrS), environmental (EnS), technological (TS), information (InS), and then resources (financial (FR), organizational and management (OMR), material and technical (MTR), labor (LR), information (IR)), ensuring the implementation of planned 
innovations is calculated. At this stage, fundamental and applied research is carried out within the specified areas (technical, organizational, management, marketing innovations), market research and a promising demand is planned for innovative products the concept of the products and/or processes of production, management and support, systems and mechanisms of the market promotion, etc. The main stages of the above method can be formalized as the following:

1. Determination of conformity of enterprise production level to the stage of the replacement model of technological structures.

1.1 Determination of strategic priorities of production development in accordance with the stages of the replacement model of technological structures.

1.2 Definition of the indicators allowing to estimatean extent of achievement of enterprise strategic objectives.

1.3 Choice of the methods for evaluating allocated indicators.

2. Assessment of the state of the enterprise source support

3. Do the results correspond to the strategic priorities of the company?

4. Identifying the innovation types required for the implementation of strategic priorities for enterprise development.

4.1 Determination of the importance of basic and improving innovation, taking into account external and internal factors of influence.

4.2 Determination of the importance of technological, organizational, managerial and marketing innovations, taking into account the weights of basic and improving innovations.

4.3 Assessment of the importance of resource clusters required for innovation (innovation implementation project).

4.4 Assessment of the importance of the resources required for innovation (innovation project).

5.Identification of funding sources for innovative project (projects).

6.Innovation implementation project (projects) at the enterprise.

7. Effectiveness assessment of the implemented project (projects).

7.1 Assessment of the expected effect of project (projects)introduction.

7.2 Assessment of implementation costs.

8. Are you satisfied with the results?

Next, the sources of financing (investment) of the implemented innovations are determined taking into account the optimal ratio of resource clusters and resources, then - the introduction of innovations.

At the final stage of the methodology implementation, the efficiency of innovation implementation is evaluated, in the process of which economic (E), social (C) and environmental (En) efficiency is determined and the cost of the innovation project is estimated. The obtained data are analyzed by the management of the enterprise and, in case of obtaining results which meet the development strategy, a decision is made on the further implementation of the chosen direction of production and/or management innovation, if the results do not meet the expected ones the deviation analysis is carried out and the measures for improvement (corrective measures) are developed.

\begin{tabular}{|c|c|c|c|c|c|}
\hline \multicolumn{6}{|c|}{$\square \mathrm{ES}-\mathrm{TrS} \square \mathrm{EnS}$} \\
\hline 18.81 & 25.4 & 2985 & 24.73 & 20.04 & 12.82 \\
\hline 33.59 & \multirow{4}{*}{$\begin{array}{c}33.94 \\
9.07 \\
15.26 \\
16.33\end{array}$} & \multirow{4}{*}{$\begin{array}{c}24.5 \\
13.78 \\
19.84 \\
12.03\end{array}$} & 19.61 & $\begin{array}{c}11.8 \\
1247\end{array}$ & 24.68 \\
\hline 10.08 & & & 9.18 & 12.41 & 23.48 \\
\hline $\begin{array}{l}10.08 \\
13.21\end{array}$ & & & 19.05 & 25.44 & 12.4 \\
\hline 24.31 & & & 27.43 & 30.25 & 26.62 \\
\hline 1 & 2 & 3 & 4 & 5 & 6 \\
\hline
\end{tabular}

Fig.2. The distribution of the resource clusters through the stages of substitution of technological modes (in \%) Source: Tolmacheva (2011)

There is a certain ratio of resource clusters at each stage of replacement of technological structure (TS). It is considered to be that the most indicative are energetic, technological and information clusters which dynamics of consumption determines the efficiency of functioning and stability of development of productive and economic systems within the regularities of long-term technical and economic development of social production.

The necessity in energy resources is the most acute at stage I of deployment of the technical structure which is associated with the consumption of energy sources for the production of basic technological 
innovations and in the subsequent operation of innovative products. Gradually, the demand for energy resources is reduced up to stage III, when the demand for energy resources increases due to its mass consumption, there is a need for new (alternative) energy sources-more energy - intensive (stage IV).

The demand for technological resources, on the contrary, is manifested in stages I and II, as there is the creation and then diffusion of basic innovations and their development on an industrial scale. Gradually, the importance of technological resources is reduced up to stages V and VI - increases sharply, due to the structural restructuring of production, focused on new types of basic innovations.

The top of demand for information resources is noted at stage III due to the increase in the share of improving organizational, managerial and marketing innovations in this period.

Figure 2 above graphically shows the percentage distribution of resource clusters in the implementation of innovation activities in the PES in accordance with the stages of the model of replacement of technological structures.

Therefore, the enterprises within their specific features can assess the importance of resources that are part of each cluster, on the basis of which - to count on the future need for the acquisition, renewal, reproduction and the like of certain types of resources. This will allow to respond to changes in the external environment in a timely manner, to ensure competitive advantages and sustainable development of production and economic systems through appropriate improvement of the internal environment.

It should be noted that the use of resource management techniques within the innovations required to achieve the goals of production and economic systems allows modeling not only the content aspects of resource provision (the choice of a significant cluster of resources in the implementation of innovation), but also to manage the economic parameters of the formation and development of resources from the standpoint of improving the overall efficiency of production and economic systems-industrial enterprises, taking into account the laws of long-term technical and economic development of social production.

\section{Conclusions}

Management of the enterprise is based on a long-term development strategy which includes specific strategic goals, reflecting the various strategic aspects in detail. Development strategy involves the choice of certain methods of achieving the goals which ensure the operation and development of the enterprise, taking into account environmental factors. The company activity is determined by the presence of a unique set of resources necessary for the implementation of basic, management and support processes. Investing in the formation and development of resource support is the key to the long-term presence of the enterprise in the relevant market of products (services).

The processes of the external environment determine the necessity to mobilize the available internal resources through the actualization of dynamic abilities aimed at ensuring competitive advantages and sustainable functioning of industrial enterprises as complex production and economic systems. The development of dynamic capabilities of the enterprises is focused, first of all, on increasing the innovative activity of production and economic systems in terms of increased competition.

With regard to the above, the strategy for the innovative process development in domestic industrial enterprises should be formed within the laws of deployment and replacement of technological structures that mediate the technical and economic state of social production, in order to ensure competitive advantages and long-term sustainable development in terms of instability and variability of the environment.

\section{References}

Alekhina O (2004) Change management: helping the organization to acquire new skills. Management Today 5: 43-46.

Ansoff I, New corporate strategy, $1^{\text {st }}$ edn. (Saint Petersburg: PiterCom. 1999), 416 p.

Avkiran N (2001) Investigating technical and scale efficiencies of Australian universities through data envelopment analysis. Socio-Economic Planning Sciences 35: 57-80. doi: 10.1016/S0038-0121(00)00010-0

Barney J (1991) Firm resources and sustained competitive advantage. Journal of Management 17 (1): 99-120. doi: $10.1177 / 014920639101700108$

Benner M (2000) Institutionalizing the triple helix: research funding and norms in the academic system. Research Policy 29 (2): 291-301. doi: 10.1016/S0048-7333(99)00067-0 
Cohen W (1990) Absorptive capacity: a new perspective on learning and innovation. Administrative Sciences Quarterly 35: 128-152. doi: 10.2307/2393553

Conceicao P (1999) On the role of the university in the knowledge economy. Science and Public Policy 26 (1): 48-56. doi: 10.3152/147154399781782617

Dodgson M, Gann D, Salter A, The management of technological innovation: strategy and practice, $1^{\text {st }}$ edn. (USA: Oxford University Press. 2008), 408 p.

Drucker P (2002) The new society of organizations. Harvard Business Review 9(10): 95-104.

Etzkowitz H (2000) The dynamics of innovation: from national systems and «Mode 2» to a Triple Helix of university-industry-government relations. Research Policy 29 (2):109-123. doi: 10.1016/S0048-7333(99)000554

Fatkhutdinov R, Management of competitiveness of the organization, $1^{\text {st }}$ edn. (Moscow: Market DS, 2008), 27 p.

Freeman C (1995) History, co-evolution and economic growth. IASA Working Paper 76: 123-134.

Korneeva E (2016) Ways of improving the comprehensive staff management system in service companies. Bulletin of the Volga State University of Service. Series: Economy 1(43): 116-123.

Korchagin P, Korneeva E, Nikitina N (2015) Factors that influence the effectiveness of Russian telecommunication companies. Economics \& Sociology 8(3):119-130. doi: 10.14254/2071-789x.2015/8-3/9

Leydesdorff L (2000) The triple helix: an evolutionary model of innovations. Research Policy 29 (2): 243-255. doi: 10.1016/S0048-7333(99)00063-3

Lisin E, Sobolev A, Strielkowski W, Garanin I (2016) Thermal efficiency of cogeneration units with multi-stage reheating for Russian municipal heating systems. Energies 9(4):269. doi: 10.3390/en9040269

Lisin E, Rogalev A, Strielkowski W, Komarov I (2015) Sustainable modernization of the Russian power utilities industry. Sustainability 7(9):11378-11400. doi: 10.3390/su70911378

Lundvall B (2002) National systems of production, innovation and competence building. Research Policy 31: 214-216. doi: 10.1016/S0048-7333(01)00137-8

Naushad M, Faridi M R, Syed A M (2018) Economic development of community by entrepreneurship: an investigation of the entrepreneurial intent and the institutional support to the local community in Al-Kharj region. Entrepreneurship and Sustainability Issues 5(4):899-913. doi:10.9770/jesi.2018.5.4(14)

Niño-Amézquita J, Dubrovsky V, Jankurová A (2017) Innovations and competitiveness in regional development: a comparison of Latin America, Europe, and China. Czech Journal of Social Sciences, Business and Economics 6(1):28-36. doi: 10.24984/cjssbe.2017.6.1.4

Overdorf M, Harvard Business Review on Innovation, $1^{\text {st }}$ edn. (Harvard Business School Press. 2007), 222 p.

Romer P (1990) Endogenous Technological Change. Journal of Political Economy 98 (5): 75-84. doi: $10.1086 / 261725$

Saaty T (2010) The scope of human values and human activities in decision making. Applied Soft Computing 10: 963-974. doi: 10.1016/j.asoc.2010.04.002

Smith K (1995) Interactions in Knowledge Systems: Foundations, Policy Implications and Empirical Methods. STI Review, OECD 16:49-53.

Shvetsova OA, Rodionova EA, Epstein MZ (2018) Evaluation of investment projects under uncertainty: multicriteria approach using interval data. Entrepreneurship and Sustainability Issues 5(4): 914-928. doi:10.9770/jesi.2018.5.4(15)

Teece D (1997) Dynamic capabilities and strategic management. Strategic management journal 18 (7): 509-537. doi: 10.1002/(SICI)1097-0266(199708)18:7\%3C509::AID-SMJ882\%3E3.0.CO;2-Z

Tolmacheva OV (2011) The directions of innovative development of the Russian industrial enterprises taking into account regularities of expansion of technological ways. Resources. Information. Supply. Competition 1:199-207.

Travin V, Magura M (2002) Staff consulting in the context of organizational changes. Staff Management 6:2534. 
Valenta F, Innovation Management, $1^{\text {st }}$ edn. (Moscow: Progress. 1985), 234 p.

Valenta F, Creative activity-innovation-effect, $1^{\text {st }}$ edn. (Moscow: Ecsmo. 2007), 400 p.

Zlyvko O, Lisin E, Rogalev N, Kurdiukova G (2014) Analysis of the concept of industrial technology platform development in Russia and in the EU. International Economics Letters 3(4):124-138. doi: 10.24984/iel.2014.3.4.2 